\title{
Improving Lesson Planning Skills of Novice teachers through Transformative Learning
}

\author{
Muhammad Azhar \\ PhD Scholar, Department of Education, International Islamic University Islamabad \\ Corresponding Author Email: muhammadazhar.te@gmail.com

\section{Dr. Muhammad Munir Kayani}

Assistant Professor, Department of Education, International Islamic University Islamabad

\section{Doi:10.5901/mjss.2016.v7n4p}

\section{Abstract}

Professional development programs play a fundamental role in shaping a community. For the improvement in quality of education, training organizations run various programs. Effectiveness of these program and performance of the teacher education institutions can be assessed by evaluating the performance of people who participate in these programs. The researchers had analyzed the professional development program of novice techers on lesson planning by usingobservational check list to observe the classroom performance of forty-eight novice teachers who participated in this program. Independent sample t-test and one way ANOVA were used for analysis. It was also found that there was no significant difference in the mean scores of novice teachers regarding professional development in the areas of lesson planning skills with respect to their designation, academic qualification and professional qualification. On the basis of findings of our study it is recommended that Government may establish a mechanism for implementation of training in classrooms by involving school heads and teacher educators. Moreover, incentives may be given to teachers for successful completion of trainings and its implementations. An environment of competition may be created for implementation of training.

Keywords: Novice teachers, Teachers training, Lesson planning skills, Classroom observation, Continuous Professional Development

\section{Introduction}

Quality education is the target and challenge for every country. Every nation tries its best to achieve this target by reserving resources for it. Policies and plans are made to achieve the target of quality education. For this purpose, capacity of workers is enhanced through training and refresher courses. New developmental changes are being occurred in society. New concepts and trends are being introduced in education. New teaching techniques and styles are being introduced in education(Coffey\& Gibbs, 2000).

Globalization is affecting every segment of education. In service teacher training program can enhance the capacity of teachers. Through affecting training, we can introduce new concepts and trends to our teachers. It is an admitted fact that quality of nation is linked with quality of education. Teacher is the most influencing person in the society.S/he is builder of destiny of nation. So profession of teaching requires more investment and facilities than any sector. These are the teachers who introduce new reforms in society. Teacher is the key component of education system (Norton et al, 2005).

Quality of education depends upon the infrastructure, dynamic curriculum, competent faculty input, process and services deserved for this purpose. Punjab Education department, since last ten years is striving its best for quality of teacher education. Punjab Education department has started continuous development program for school teachers under the umbrella of Directorate of Staff Development Punjab, Lahore. Directorate of Staff Development has imparted a number of trainings since its reformation.Since 2004, the Directorate of Staff Development has been restructured as the "climaxinstitute" with the authorization to develop value based programs of teacher education across the public sector schools through integrated and joint efforts with the education department. The vision of the Directorate is "to develop a committed,knowledgeable, motivated, competentand ethically sound cadre of educational personnel to convey top quality education to the students in government schools" (Govt. of Punjab, 2009).

Professional development is key factor in delivery of quality education. Basic purpose of staff development program is to enhance the capacity of teachers. Directorate of Staff development, through its professional development program, is trying to enhance pedagogical skills of novice teachers. Directorate of staff Development Punjab has 
organized a professional development program for Elementary School Educators, Senior Elementary School Educators and Secondary School Educators who were recruited in last three years $(2010,2011$ and 2012) in Punjab (Govt. of Punjab, 2012). Research was aimed to evaluate the improvement in lesson planning skills of novice teachers through transformative learning.

\section{Review of Literature}

Lesson planning gives a real insight into the extra ordinary alchemy of teaching. Some people think that teacher has to turn up to the classroom and has to deliver some contents to a student. The class is orderly, the teaching material easily comes to the hand, student's respond in well way to the question or the direction given by the teacher, and the learning atmosphere is always supported. The teacher is confident and act of teaching appears effortless. Question posed by the teachers are considered seriously by the students who want to respond the answers. There is a little disruption, everyone seems to understand their role in learning process and will go about the job with a positive sense of purposefulness (Cowley, 2006).

A teacher has to bring to the classroom, pedagogic and subject related knowledge that a teacher does not possess at early stages. The teachers who have well experience of teaching have well collection of lesson activities to deliver in a class. They present activities according to the situation in class. Affective lesson planning takes time and requires a range of skills (Turner, 1999).

Poor classroom practice is bad behavior of students and poor assessments tasks can be linked with unsatisfactory planning. Under the surface of a good lesson, there is bed rock of teachers understanding of the principals of suitable pedagogic practices. These principals are derived from an appreciation of how children learn from the self knowledge that arises from being reflective teachers. The successful lesson planning is associated to the evaluation of lessons previously presented. An effective teacher deals classroom problems with an effective lesson planning and preparation (Harvey, 2003).

Many experienced teachers face real problems when they are going to plan lesson.Some time they have to face problems to capturestudent's attention and sometime they make wrong estimate regarding abilities of students. Lesson planning is permanent and continuous process and it should remain continue (Postareff, Lindblom-Ylanne \& Nevgi, 2007).

\subsection{Key Factors in Lesson Planning}

A numbers of factors are considered in planning process. Some factors are obvious and straightforward. Some factors may be required only for teaching of a new group.Some factors are related to unfamiliar learning situation while some factors may be considered for adopting anew teaching methodology. Planning may be more complex whenever, a new situation will arise in teaching learning process(Ediger, 2007).

For a better lesson planning, a teacher has to consider following factors:

1 The ability of student of whom you are going to teach?

2 What have to learn students in your sessions?

3 The ways through which learners will learn in best way?

It is important to realize that foundations that relate to good planningare to look at knowledge and understanding of how groups and individuals learn, subject knowledge,abilities, age of the students, and assessment (Harvey, 2003).

There are some questions that you may need to consider when starting to plan a lesson:

1 What is the scheme of work that is being followed by the students?

2 What was taught andlearnt in the previous lesson?

3 What are your learning objectives of the lesson, you are planning?

4 How your lesson plan will facilitate learning?

5 Which resources will be required?

6 In which activities, students will participate?

Three further questions will arise after the planned lesson has been delivered.

- How you will come to know what the students have learned (Assessment)?

- How will you come to know how this lesson has been affective from teachers prospective and students prospective (Evaluation)?

- What action will be required for affective learning in future?(Gibbs \& Coffey, 2004).

By analyzing these three questions, four major components of the lesson arise: 
1 The purpose of the lesson (Expected learning outcomes).

2 The substances of the lesson (The subject matter, understanding and skills).

3 The methods of the lesson (The strategies used to ensure learning).

4 The evaluation of the lesson (Students learning)(Holmes, 2004).

Transformative learning and its procedure of occurrence has well been explained by transformative learning theory. Transformative means a non-reversible shift towards greater inclusiveness and permeability. It must carry flexibility, autonomy, discrimination and openness. The theory explained that through a certain developmental process, the views of individual groups or organizations are changed. A person's basic belief or assumption about any work is his meaning perspective. Thus, transformation theory deals with changing a qualified individual to a skilled worker (Mezirow, 2000).

\section{Objectives of the study}

1 To investigate professional development of novice teachers in the area of lesson planning skills in context of Transformative learning.

2 To compare the lesson planning skills of novice teachers in context of transformative learning.

\section{Research Hypotheses}

$\mathrm{H}_{0} 1$ There is no significant difference in the mean scores of Elementary, Senior Elementary and Secondary School novice teachers regarding professional development of lesson planning skills in context of transformative learning.

$\mathrm{H}_{0} 2$ There is no significant difference in the mean scores of lesson planning skills in context of transformative learning with respect to academic qualification of novice teachers.

$\mathrm{H}_{0} 3$ There is no significant difference in the mean scores of lesson planning skills in context of transformative learning with respect to professional qualification of novice teachers.

\section{Population of Study}

There were 78092 Elementary School Educators, Senior Elementary School Educators and Secondary School Educators who were recruited in 2010, 2011 and 2012, and were imparted four week induction training by Directorate of staff Development Punjab, Lahore in 36 districts of Punjab (Govt. of Punjab,2012).

\section{Sample Selection Procedures}

Multi stage sampling technique was used to select the sample. In first stage, researcher included Districts i.e. Bahawalpur, Dera Ghazi Khan, Faisalabad, Gujranwala, Kasur, Rahim Yar Khan, Rawalpindi and Sargodha where the number of Novice Teachers per district was more than 1500 who were recruited in education department and were trained through induction professional development program. In second stage, forty eight novice teachers were observed in their classrooms by randomly selecting two novice teachers from every stratum of Elementary School Educators, Senior Elementary School Educators and Secondary School Educators of eight selected districts.

\section{Research instrument}

A self designed observation check list based on 3 point Guttman scale Yes, To Some Extent, No was used to find out transformation among novice teachers by observing them in classrooms. Its items were related to student learning outcomes, activities, low cast no cast material and lesson planning skills. We personally visited to observe the classroom teaching of these teachers.

\section{Analyses and Interpretation of Data}

The first hypothesis stated that there is no significant difference in the mean scores of Elementary, Senior Elementary and Secondary School novice teachers regarding professional development of lesson planning skills in context of transformative learning. 
For the analysis of this hypothesis, one Way ANOVA was used at significance level of 0.05 . Before running ANOVA, assumptions were tested and met.

Table 1: Teachers Designation: Lesson Planning Skills

\begin{tabular}{cccc}
\hline & $\boldsymbol{d f}$ & $\boldsymbol{F}$ & $\boldsymbol{p}$ \\
\hline Between Groups & 2 & .450 & .641 \\
Within Groups & 45 & & \\
Total & 47 & &
\end{tabular}

Table 1 showed results of one way ANOVA. The results concluded that there was no significant difference in the mean scores of Elementary, Senior Elementary and Secondary School novice teachers regarding professional development of lesson planning skills in context of transformative learning $(F(2,45)=0.450, p=.641)$. Hence, $\mathrm{H}_{0} 1$ was accepted.

Table 2: Academic Qualification: Lesson Planning Skills

\begin{tabular}{cccc}
\hline Academic Qualification & Mean & Std. Deviation & N \\
\hline Bachelor & 11.9333 & 1.90738 & 15 \\
Master & 11.6875 & 1.92501 & 32 \\
M Phil & 13.0000 & 1.92201 & 1 \\
Total & 11.7917 & 1.89016 & 48
\end{tabular}

The analysis of descriptive statistics related to academic qualification and total lesson plan scores showed that bachelor degree holders ( $M=11.93, S D=1.907, N=15)$, master degree holders $(M=11.68, S D=1.92, N=32), M$ Phill degree holders $(\mathrm{M}=13.0, \mathrm{SD}=1.89, \mathrm{~N}=1)$ had slight differences in their mean scores.

\section{Qualification of Novice Teachers}

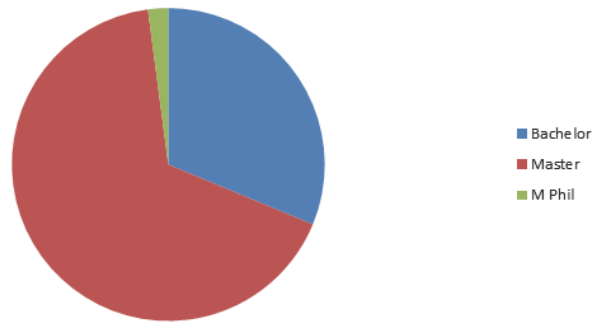

Figure 1: Showing pie graph regarding qualification of novice teachers

Figure 1 shows that maximum novice teachers master degree holders. On the other hand minimum teachers were M. Phil. Degree holders. This implies that the teachers of concerned schools needed to enhance their qualifications.

Second null hypothesis stated that there is no significant difference in the mean scores of lesson planning skills in context of transformative learning with respect to academic qualification of novice teachers.

For the analysis of this hypothesis, one Way ANOVA was used at significance level of 0.05 .Before running ANOVA, assumptions were tested and met.

Table 3: Total Lesson Planning Score w.r.t. Academic Qualification

\begin{tabular}{cccc}
\hline & $d f$ & $\boldsymbol{F}$ & $\boldsymbol{p}$ \\
\hline Between Groups & 2 & .286 & .753 \\
Within Groups & 45 & & \\
Total & 47 & &
\end{tabular}

Table 3 showed results of one way ANOVA. The results indicated that there was no significant difference in the mean 
scores of lesson planning skills in context of transformative learning with respect to academic qualification of novice teachers. $(F(2,45)=.286, p=.753)$. So, Hence, $\mathrm{H}_{0} 2$ was accepted.

Table 4: Descriptive Statistics of Lesson Plan Scores w.r.t. Professional Qualification

\begin{tabular}{cccc}
\hline Professional Qualification & N & Mean & Std. Deviation \\
\hline B Ed & 40 & 11.5750 & 1.81005 \\
M Ed & 8 & 12.8750 & 2.03101
\end{tabular}

The analysis of descriptive statistics related to professional qualification and total lesson plan scores showed that $B$ Ed degree holders ( $M=11.5750, S D=1.81005, N=40), M$ Ed degree holders $(M=12.8750, S D=2.03101, N=8)$ had differences in their mean scores. M Ed degree holders had slight better mean scores than B Ed degree holders.

Third hypothesis stated that there is no significant difference in the mean scores of lesson planning skills in context of transformative learning with respect to professional qualification of novice teachers. For the analysis of this hypothesis, an independent Sample t Test was used at significance level of 0.05 .

Table 5: Lesson Planning: Professional Qualification

\begin{tabular}{lccccc}
\hline & \multicolumn{3}{c}{ Levene's Test for Equality of Variances } & \multicolumn{3}{c}{ Independent sample t-test } \\
\cline { 2 - 5 } & $\boldsymbol{F}$ & $\mathrm{Sig}$ & $\boldsymbol{t}$ & $\mathrm{df}$ & $\boldsymbol{p}$ \\
\cline { 2 - 6 } Equal variances assumed & .115 & .736 & -1.819 & 46 & .075 \\
Equal variances not assumed & & & -1.682 & 9.358 & .126 \\
\hline
\end{tabular}

Table 5 indicated that there was no significant difference in the mean scores of lesson planning skills in context of transformative learning with respect to professional qualification i.e. B $E d(M=11.57, S D=1.81)$ \& $M \quad E d(M=$ $12.87, \mathrm{SD}=2.03)$ of novice teachers as $(t(46)=-1.819, \mathrm{p}=.075)$.

\section{Discussion}

Professional development is a method of enhancing human workability. Whenever a person's ability to perform a job lacks knowledge or skills, the gap is bridged by providing the required instruction (Silberman, 2006). Professional development is a continuous and a lifelong process (Cowley, 2006). The use of transformative learning theory in the educational context had many contributive elements like higher education (Barlas, 2000; Cohen \& Piper, 2000; Glisczinski, 2005; Taylor, 2000), corporate human resources development (Yorks \&Marsick, 2000), academic committees (KasI\& Elias, 2000), community education (Silverman, 2004; Waithe, 2005) and professional development for teachers (Dumochel, 2004; King, 2002; Saavedra, 1995; Smith, 1999). The study undertaken had focused on how transformative learning could be facilitated in specific educational situation for specific learners. In a study, Norton et al. (2005) found no differences in teaching attitude and intent between teachers who had joined training programs and teachers who had no attended training. However, positive results of the effectiveness of teacher trainings have also been presented. Coffey and Gibbs (2004) showed, by using the approaches to teaching inventory that by the end of the 4 month training programs, teacher-centered approach changed into student-centre approach. Similarly, Coffey and Gibbs (2000) found positive effects of teacher training on academics' teaching. However, Postareff et al. (2007) showed that approaches to teaching change slowly. Douglas and Tim (2011) concluded that here is no evidence that teachers' pre-service trainings are related to productivity. Gao\& Wang (2014) showed that different teaching experiences of the teachers and their school cultures of teaching interacted with the centralized curriculum and teacher teaching community shape their teaching practices in different ways.Kemmis et al. (2014) concluded that effect of training a teacher varies according to social, political and cultural situation of learning arrangements. It is concluded that in-service teacher training programs are necessary for capacity building of teachers of school education.

In this study, the novice teachers were observed during classroom practices to find the level of transformation. The analysis of data was done through ANOVA and independent sample t-test. It was found that lesson planning skills taught by the master trainer were efficiently adopted by the novice teachers with effective results. The perspective transformation of lesson planning skills was inspected by Barlas (2000). His point of attention was to look how lesson planning skills were promoted through the linkage between personal transformation and subsequent actions. The framework of action research and collaborative inquiry was used by Yorks and Marsick (2000) to explain the role of 
organizational transformation in developing lesson planning skills. It was also asserted by Kasl and Elias (2000) that the lesson planning skills were enabled by transformative learning.

\section{Conclusions}

1. There was no significant difference in the mean scores of novice teachers regarding professional development in the areas of lesson planning skills with respect to their designation.

2. There was no significant difference in the mean scores of novice teachers regarding professional development in the areas of lesson planning skills with respect to their academic qualification.

3. There was no significant difference in the mean scores of lesson planning skills of novice teachers in context of transformative learning with respect to their professional qualification.

\section{Recommendations}

1. Government may establish a mechanism for implementation of training in classroom by involving school heads and teacher educators.

2. Incentives may be given to teachers for successful completion of trainings and its implementations.

3. An environment of competition may be created for implantation of training.

4. Training may be evaluated by third party for its impartial evaluation.

\section{References}

Barlas, C. (2000). Towards a changing paradigm: Transformative learning and social change action. Dissertation Abstracts International. (UMI No. 9961564)

Cohen, J.B. \& Piper, D. (2000) Transformation in a residential adult learning community. In J. Mezirow (Ed.), Learning as transformation: Critical perspectives on a theory in progress. San Francisco: Jossey-Bass.

Coffey, M., Gibbs, G. (2000).Can academics benefit from training? Some preliminary evidence.Teaching in HigherEducation, 5, 385389.

Coffey, M., Gibbs, G. (2004).The impact of training of university teachers on their teaching skills, their approach to teaching and the approach to learning of their students. Active Learning in Education, 5, 87-100.

Cowley, S. (2006). How to survive your first year in teaching. London: Continum.

Douglas, N., Tim, R. (2011). Teacher training, Teacher quality and Students achievement.Journal of Public Economics 2011, Volume 95, Issues 7-8, pp.798-812.

Dumochel, D.M. (2004). Facilitating teachers' growth: Investigating the factors that contribute to the effectiveness of intensive professional development programs for educators. Dissertation Abstracts International. (UMI No. 3135470)

Glisczinski, D.J. (2005). Transformative teacher education: A meaningful degree of understanding. Dissertation Abstracts International. (UMI No. 3188558)

Govt. of Punjab, (2009).Situation Analysis of Teacher Education in Pakistan.

Govt. of Punjab, (2012). Notification No RPM-1 (DSD) 978-1/2012 Dated:10th Oct,2012.

Holmes, E. (2004). The Newly Qualified Teachers Handbook. London: Kogan Page.

Kasl, E. \& Elias, D. (2000).Creating new habits of mind in small groups. In J. Mezirow (Ed.), Learning as transformation: Critical perspectives on a theory in progress. (p. 229-252). San Francisco: Jossey-Bass.

King, K.P. (2002). Keeping pace with technology: Educational technology that transforms. Volume One: The challenge and promise for K-12 educators. Cresskill, NJ: Hampton Press, Inc.

Kemmis, S., Hannu, L.T., Heikkinen, F. G., Aspfors, J., Edwards-Groves, C. (2014).Mentoring of new teachers as a contested practice: Supervision, support and collaborative self-development.Journal of Teaching and Teacher Education, Volume 43, October 2014,

Harvey, B. A. (2003). The Dialogue between education research and paractice. (R. Begg, Ed.) London: Kluwer acdemic publishers.

Turner, L. B. (1999). Sharing Experties and Teacher Education. New York: Cassell.

Ediger, D. B. (2007). Encylopeadia of Teaching. (Vol. 1). New Dehli: Discovery Publishing House.

Mezirow, J. (2000). Learning to think like an adult.Core concepts of transformation theory. San Francisco: Jossey-Bass.

Norton, L., Richardson, J. T. E., Hartley, J., Newstead, S., Mayes, J. (2005). Teachers' beliefs and intentions concerning teaching in higher education. Higher education, 50, 537-571.

Postareff, L., Lindblom-Ylanne, S., \& Nevgi, A. (2007).The effect of pedagogical training on teaching in school. Teaching and Teacher Education, 23, 557-571.

Saavedra, E.R.M.M. (1995). Teacher transformation: Creating texts and contexts in study groups. Dissertation Abstracts International. (UMI No. 9531120)

Silberman, M. (2006). Active Training. (3rd ed.). San Francisco: Pfeiffer.

Silverman, M. (2004). Community learning in environmental NGO projects in Vietnam: A comparative study. Dissertation Abstracts 
International. (UMI No. 3155479)

Smith, B.J. (1999). Transformative professional development: Discovering teachers' concepts of politicized classroom practice. Dissertation Abstracts International. (UMI No. 9933154)

Gao,S., Wang, J. (2014). Teaching transformation under centralized curriculum and teacher learning community: Two Chinese chemistry teachers' experiences in developing inquiry-based instruction.Journal of Teaching and Teacher Education, Volume 44, November 2014

Taylor, E. (2000). Analysing research on transformational learning theory. San Francisco: Jossey-Bass.

Waithe, W.E. (2005). Community coalitions as sites of transformative learning.Dissertation Abstracts International. (UMI No. 3177569)

Yorks, L. \&Marsick, V.J. (2000) Organizational learning and transformation. In J. Mezirow (Ed.), Learning as transformation: Critical perspectives on a theory in progress. San Francisco: Jossey-Bass 